\title{
Clarifying The Meaning Of Extracurricular Activity: A Literature Review Of Definitions
}

\author{
Kenneth R. Bartkus, Utah State University, USA \\ Blake Nemelka, Utah State University, USA \\ Mark Nemelka, Utah State University, USA \\ Phil Gardner, Michigan State University, USA
}

\begin{abstract}
Participation in extracurricular activities has long been recognized as having important benefits for business students, including the development of competencies relevant to future career success. Unfortunately, a review of the literature suggests that what constitutes an extracurricular activity remains ambiguous and unclear as no generally-accepted definition has been established in the literature. Instead, the meaning is often described in terms of examples. It is argued that the lack of a definition hampers research because it does not allow for proper classification of activities. The purpose of this study is to address this gap through a review of the relevant literature. Based on the review, definitions for extracurricular and co-curricular are proposed along with additional clarifications. Implications for scholars and academic advising are also provided.
\end{abstract}

Keywords: Curricular; Extracurricular; Co-Curricular; Definition

\section{INTRODUCTION}

tudent participation in extracurricular activities (ECA) has been identified as an important aspect of the education experience (Cole, Rubin, Feild, and Giles, 2007). Some of the accumulated evidence suggests that student participation in ECA is indicative of competencies that are relevant to the development of a successful business career. For example, Boone, Kurtz, and Fleenor (1988) surveyed CEOs from large U.S. industrial corporations and found that they had considerably higher involvement in extracurricular activity during their college years than did other students. Rubin, Bommer, and Baldwin (2002) found that business students who participated in ECAs demonstrated higher interpersonal competency skills. Similarly, Rynes, Trank, Lawson, and Ilies (2003) surveyed recruiters and found that business student participation in ECAs was viewed as an effective way to instill leadership and interpersonal skills. Chia (2005) found that accounting student participation in ECAs was associated with the number of initial interviews obtained by graduating seniors.

Participation has also been shown to transcend career success. In particular, Clotfelder (2001) studied alumni donor characteristics and found that the level of contribution was associated with having participated in extracurricular activities in college.

Unfortunately, a review of the extant literature reveals a potentially important gap in ECA research; namely, there is an apparent lack of a generally-accepted definition. Perhaps as a result, the concept has commonly been treated as self-explanatory with little need for clarification. For example, Rubin, Bommer, and Baldwin (2002) state, "One intuitive notion is that extracurricular activities are a place where students look to utilize, and perhaps refine and develop, their interpersonal skills." (p. 443)

Additionally, when extracurricular is described, it is often in the form of examples. For example, Barnett (2007) notes that "....schools encourage students to participate in various extracurricular activities, such as athletics, 
vocational clubs, student government, newspapers and yearbooks, and special interest groups" (p. 316). Similarly, Keser et al. (2011) note that Bîrzéa and colleagues (2004) describe extracurricular activities "to be part of nonformal curriculum and they range from visits to different settings and institutions, school exchanges, voluntary work, and student organizations to student clubs and projects outside the school. They may take place after and during school programmes and both in and out of school buildings." (p. 812) Finally, some researchers describe extracurricular activities through the use of synonyms, such as "non-academic endeavors" (Chia, 2005, p. 76) or "out-of-class experiences" (Nelson et al. 2002, p. 278).

The lack of a generally-accepted definition suggests at least one important implication for research, specifically, Adams (2002) has argued that:

- $\quad$ Definitions precede classification

- $\quad$ Classification enables analysis

- $\quad$ Analysis allows critical reasoning

- $\quad$ Critical reasoning contributes to creative problem solving

Hence, a lack of a formal definition can serve to limit a researcher's ability to classify extracurricular activity, which in turn limits to conduct a thoughtful analysis, engage in critical reasoning, and enable creative problem solving. Even a brief review of the literature provides preliminary support for this proposition, particularly with regard to classification. For example, "reading a book" has been identified as an extracurricular activity (e.g., McGaha and Fitzpatrick, 2010) as has "marriage (e.g., Ahadiat and Smith, 1994). To further complicate matters, some studies measure participation in terms of the number of extracurricular activities without consideration of relevancy, such as leadership roles (e.g., Kinicki and Lockwood, 1985; Howard, 1986). One could argue that such measurement practices are acceptable because the literature has been basically silent on what defines an extracurricular activity.

The fact that extracurricular activity has been measured differently in the literature has been considered problematic. Fredricks and Eccles (2006a), for example, state that: “...until recently, many studies either have assessed activity participation with dichotomous measures (i.e., yes or no) or have aggregated all extracurricular activities together into a single indicator. Recently, some researchers have taken a more nuanced view of activity participation and have looked at differences in the relations by type of activity (e.g., Eccles \& Barber, 1999; Fredricks \& Eccles, 2006b; Hansen et al., 2003).” (p. 699) Marsh and Kleitman (2002) also acknowledge problems with measurement and state that the selection "of a single extracurricular activity addresses neither the generalizability of the effects across different activities nor the combined effects of participation in many different activities." (p. 465)

The current study argues that the lack of a generally-accepted definition serves to impede our understanding of the role that extracurricular activities play in the education and career equation because it does not provide adequate guidance on how they should be classified. And, without the ability to systematically classify extracurricular activities, it becomes increasingly difficult to develop valid research designs and, as Adams (2002) argues, engage in critical analysis and creative problem solving. The purpose of this study, therefore, is to propose a formal definition and provide guidelines for the measurement of extracurricular activities. This is addressed through a review and synthesis of the literature.

\section{LITERATURE REVIEW}

A useful starting point for developing a better understanding of extracurricular activity is to examine the meaning of the root term "curricular". The Free Dictionary states that the term curricular is the adjective form of the noun curriculum which refers to: (1) all the courses of study offered by an educational institution and (2) a group of related courses, often in a special field of study. (http://www.thefreedictionary.com/curricular). Curricular is then defined by the Free Dictionary as: "of or relating to an academic course of study". These basic definitions were found to be relatively consistent across other dictionaries as well. 
If we then examine the meaning of the prefix term "extra", we find that it is defined as something: "More than or beyond what is usual, normal, expected, or necessary" (http://www.thefreedictionary.com/extra). Hence, extracurricular is defined as "Being outside the regular curriculum of a school or college" (http://www.thefreedictionary.com/extracurricular)

While this definition provides a basic meaning for extracurricular, one might argue that it is overly broad since is allows virtually anything outside of the regular curriculum to be considered as an extracurricular activity. In this sense, it is not all that surprising that some studies have regarded 'reading a book' or 'marriage' as extracurricular activities.

To help extend our understanding of extracurricular activity, a library search of the scholarly literature was conducted using the identifier "extracurricular". The results revealed no clear definition. Instead, the meaning of extracurricular was typically assumed to be intuitive and/or explained through the use of descriptors. With regard to intuition, Clegg, Stevenson and Willott (2010) examined perceptions of extracurricular activities by educational staff in the U.K. and noted that "The little work that recognises the potential benefits of ECA, however, relies on an assumed common sense definition of extracurricular...)" (p. 617, italics added for emphasis) Ironically, the "common sense" definition does not appear to have been presented, nor was an alternative, but they note that the "default understanding of ECA would appear to include campus-based cultural and sporting activities, and volunteering." (p. 616)

This default understanding may help explain the apparent diversity in the way ECAs has been described in the literature. Perhaps the most common approach to explaining the meaning of ECAs has through the use of descriptors, either in terms of activities or characteristics. Barnett (2007), for example, described ECAs in terms of activities: “...athletics, vocational clubs, student government, newspapers and yearbooks, and special interest groups" (p. 316). Similarly, McGaha and Fitzpatrick (2010) described ECAs as "participation in school and neighborhood activities" (p. 24) Fredricks and Eccles (2006) also described ECAs by way of activities: "Both scholars and youth policy advocates argue that participation in high-quality extracurricular activities, such as sports and school clubs, is a productive use of adolescents' leisure time..." (p. 698)

Alternatively, Rubin, Bommer, and Baldwin (2002) categorized extracurricular activities and placed them one of two categories: 'clubs and organizations' and 'offices held in organizations'. The categorical approach was also used by Eccles et al. (2003) who described extracurricular activities in terms of: (1) pro-social activitieschurch attendance and/or volunteer and community service type activities, (2) performance activities - school band, drama, and/or dance, (3) team sports — one or more school teams, (4) school involvement—student government, pep club, and/or cheerleading and, (5) academic clubs - debate, foreign language, math, or chess clubs, science fair, or tutoring in academic subjects.

Belikova (2002) described ECAs according to when they occur: "in a time that is free from school work..." (p. 74). This is consistent with the view of both Christensen (2002), who described them as "activities outside the classroom" (9), and Nelson, Vendrzyk, Quirin, and Allen (2002) who described ECAs as "Outside-of-class" experiences (p. 278) Other descriptions include those by Chia (2005) who described ECAs as "non-academic endeavors" (p. 76) and Mahoney, Cairns, and Farmer (2003) who described ECAs as "structured, challenging, and voluntary" (p. 410)

The preceding discussion suggests that the lack of a generally-accepted definition may have hampered our understanding of what constitutes a valid extracurricular activity. In turn, this may have led to overly broad diversity in the way ECA has been operationalized in empirical research. To better understand this issue, the literature was reviewed to identify how ECA has been operationalized. A summary is presented in Table 1. 
Table 1: The Measurement of Extracurricular Activities

\begin{tabular}{|c|c|}
\hline Authors & Operational Categories \\
\hline $\begin{array}{l}\text { Ahadiat, Nasrollah \& } \\
\text { Kenneth J. Smith (1994) }\end{array}$ & Hobbies, participation in sports, marital status, and participation in company-sponsored events. \\
\hline Barnett (2007) & Dance and cheerleading \\
\hline $\begin{array}{l}\text { Brown \& Campion } \\
\text { (1994) }\end{array}$ & $\begin{array}{l}\text { Professional society, Elected office, Varsity athletics captain, Recreational sport, Community } \\
\text { activities, College clubs, Social fraternity }\end{array}$ \\
\hline Campion (1978) & $\begin{array}{l}\text { Membership/leadership in college clubs or committees or other professional organizations besides a } \\
\text { fraternity or sorority }\end{array}$ \\
\hline Chia (2005) & Leadership appointments such as Chairperson of students' society or association \\
\hline Clotfeldler (2001) & $\begin{array}{l}\text { In addition to activities such as publications, government, and cheerleading, also includes resident } \\
\text { advisor, ROTC, and volunteering. }\end{array}$ \\
\hline $\begin{array}{l}\text { Cole, Rubin, Feild, \& } \\
\text { Giles (2007) }\end{array}$ & $\begin{array}{l}\text { Member of professional societies, member of college clubs, has held elected offices, member of } \\
\text { social fraternity or sorority, volunteered for community activities }\end{array}$ \\
\hline $\begin{array}{l}\text { Kerr and Colangelo } \\
\text { (1988) }\end{array}$ & $\begin{array}{l}\text { Membership in instrumental music, vocal music, student government, publications, debate, } \\
\text { department clubs, drama/theater, religious organizations, ethnic organizations, intramural sports, } \\
\text { varsity sports, political organizations, Radio/TV. Fraternity/sorority, special interest groups, service } \\
\text { organizations. }\end{array}$ \\
\hline $\begin{array}{l}\text { Kinicki \& Lockwood } \\
\text { (1985) }\end{array}$ & $\begin{array}{l}\text { Number of memberships in social fraternities or sororities, amount of volunteer experience, } \\
\text { frequency of participation in college athletics, number of memberships in organizations (excluding } \\
\text { social fraternity or sororities), number of offices held in organizations, assessed an interviewee's } \\
\text { level of involvement or accomplishment in these activities. }\end{array}$ \\
\hline $\begin{array}{l}\text { Mahoney, Cairns, \& } \\
\text { Farmer (2003) }\end{array}$ & school-sponsored extracurricular activities \\
\hline Marsh (1992) & $\begin{array}{l}\text { Varsity athletic teams, Other athletic teams-in or out of school, Cheerleading, Cheerleaders, pep } \\
\text { club, majorettes, Drama/debate, Debating or drama, Music, Band or orchestra, Dance/chorus, } \\
\text { Chorus or dance, Hobby clubs, Hobby clubs such as photography, model building, hot rod, } \\
\text { electronics, craft, School subject clubs, School subject matter clubs such as science, history, } \\
\text { languages, business, art, Vocational education clubs, Vocational education clubs such as Future } \\
\text { Homemakers, Teachers, Farmers of America, DECA, FBLA, or VICA, Community youth clubs, } \\
\text { Youth organizations in the community such as scouts, Y, Church activities, Church activities } \\
\text { including youth groups, Junior achievement, Junior achievement Publications, School newspaper, } \\
\text { magazine, yearbook annual, Student government, Student council, student government, political } \\
\text { club, Service clubs, Service clubs or other community service activities, Honor societies, Honorary } \\
\text { clubs, such as Beta Club or National Honor Society, Fraternity/sorority. }\end{array}$ \\
\hline $\begin{array}{l}\text { Marsh and Kleitman } \\
(2002)\end{array}$ & $\begin{array}{l}\text { Sports- Baseball or softball, Basketball, Football, Soccer, Swim team, Other team sport, Other } \\
\text { individual sport, Team sport, Individual sport, Cheerleading, Pom-pom, Performing arts, Band or } \\
\text { orchestra, Drama club, Academic activities, Science fairs, Academic clubs, Academic honors } \\
\text { society, Newspaper/ yearbook, Student newspaper/yearbook, Student service/ government, Student } \\
\text { council, Service clubs (AFS, Key Club),Vocational clubs (FTA, FHA, FFA, or other vocational } \\
\text { education or professional club), Hobby clubs (photography, chess, etc.) }\end{array}$ \\
\hline $\begin{array}{l}\text { McGaha \& Fitzpatrick } \\
(2010)\end{array}$ & $\begin{array}{l}\text { The extracurricular activities assessed in this study were: (a) read papers/magazines; (b) read books; } \\
\text { (c) use computer at home; (d) use internet for information; (e) watch TV news; (f) engage in } \\
\text { physical fitness; (g) go to public library; (h) attend plays/concerts; (i) engage in organized religion; } \\
\text { (j) participate in sports; (k) volunteer at youth center; and (l) participate in political campaign }\end{array}$ \\
\hline $\begin{array}{l}\text { Nemanick and Clark } \\
(2002)\end{array}$ & Membership/leadership in organizations/clubs \\
\hline Paguero (2011) & $\begin{array}{l}\text { Based on the student's involvement with two forms of extracurricular activities offered by the } \\
\text { school: academic (i.e., band, orchestra, chorus, or choir; school play or musical; student } \\
\text { government; achievement-related honor society; or school yearbook, newspaper, or literary } \\
\text { magazine) and interscholastic sports (i.e., baseball, softball, basketball, football, soccer, } \\
\text { cheerleading/drill team, or other team or individual sport). }\end{array}$ \\
\hline $\begin{array}{l}\text { Raymond, Carlson and } \\
\text { Hopkins (2006) }\end{array}$ & Clubs and organizations along with offices held. \\
\hline $\begin{array}{l}\text { Rubin, Bommer, \& } \\
\text { Baldwin (2002) }\end{array}$ & $\begin{array}{l}\text { Member of a club, organization, fraternity, sorority, or sports team. Also, if the student was an } \\
\text { officer or captain in any of these groups it was mentioned }\end{array}$ \\
\hline
\end{tabular}


The data from Table 1 indicates considerable variance in both the nature and scope of ECA. Could the absence of a definition of extracurricular activity be a cause? Although one cannot know for sure, it appears that the absence of a definition did not help.

Given (1) the limited clarification provided through the scholarly literature and (2) the wide variance in the measurement of extracurricular activity, the review was then extended to a general Internet search using the identifiers "extracurricular" and "definition" (or "defined"). This resulted in more than 400,000 "hits". Relevant sites within this list were reviewed for definitional content until redundancy was found. At that point, further review was suspended and representative definitions were selected. Although neither a complete audit nor a systematic analysis, the results reveal useful evidence that tends to be more complete and/or comprehensive than those found in the scholarly literature. A sample of representative definitions is summarized in Table 2 (italics added for emphasis).

Table 2: Representative Examples of Definitions/Descriptions of Extracurricular Activity from Practitioners/Popular Press

\begin{tabular}{|c|c|}
\hline Source & Definition/Description (italics added for emphasis) \\
\hline $\begin{array}{l}\text { Wikipedia: } \\
\text { http://en.wikipedia.org/wiki/Extracurricular }\end{array}$ & $\begin{array}{l}\text { Extracurricular activities are activities performed by students that fall outside } \\
\text { the realm of the normal curriculum of school or university education. } \\
\text { Such activities are generally voluntary as opposed to mandatory, non-paying, } \\
\text { social, philanthropic as opposed to scholastic, and involve others of the same } \\
\text { age. Students often organize and direct these activities under faculty } \\
\text { sponsorship, although student-led initiatives, such as independent newspapers, } \\
\text { are common. }\end{array}$ \\
\hline $\begin{array}{l}\text { Rodel Foundation of Arizona } \\
\text { http://www.rodelfoundationaz.org/mac- } \\
\text { ro/taxcredit.aspx }\end{array}$ & $\begin{array}{l}\text { Extracurricular activity means any optional, non-credit educational or } \\
\text { recreational activity that supplements the education program of the school. } \\
\text { Activities such as tutoring, sports, visual and performing arts, special } \\
\text { programs, field trips, character education, clubs or outdoor education can be } \\
\text { funded with tax credit money. }\end{array}$ \\
\hline $\begin{array}{l}\text { Chico Unified School District } \\
\text { http://www.cusd.chico.k12.ca.us/ jzertuch/Co } \\
\text { unseling/hbext.html }\end{array}$ & $\begin{array}{l}\text { An extracurricular activity is not part of the regular school curriculum, is not } \\
\text { graded, does not offer credit, and does not take place during classroom time. }\end{array}$ \\
\hline $\begin{array}{l}\text { Mary Elizabeth } \\
\text { What are Extracurricular Activities? } \\
\text { http://www.wisegeek.com/what-are- } \\
\text { extracurricular-activities.htm }\end{array}$ & $\begin{array}{l}\text { Extracurricular activities are opportunities to engage in extensions of academic } \\
\text { activities and/or non-academic activities under school auspices. In special } \\
\text { circumstances, for example, when there are budget or scheduling constraints, } \\
\text { extracurricular activities may provide experiences that would otherwise be } \\
\text { offered within the school day. }\end{array}$ \\
\hline $\begin{array}{l}\text { American Heritage Dictionary } \\
\text { http://education.yahoo.com/reference/dictionar } \\
\text { y/entry/extracurricular }\end{array}$ & $\begin{array}{l}\text { Being outside the regular curriculum of a school or college: Sports and drama } \\
\text { are the school's most popular extracurricular activities. }\end{array}$ \\
\hline $\begin{array}{l}\text { Michigan State University Web Site } \\
\text { https://www.msu.edu/ almardan/Webquest/ext } \\
\text { racurricular_activities.htm }\end{array}$ & Extracurricular activities are what you do outside of the classroom. \\
\hline $\begin{array}{l}\text { Cumberland Public Schools Co-Curricular and } \\
\text { Extracurricular Activities - general Policy } \\
\text { http://www.cumberlandschools.org/website/Int } \\
\text { erscholastic\%20Sports.pdf }\end{array}$ & $\begin{array}{l}\text { Extracurricular programs are defined as those activities that broaden the } \\
\text { educational experience which usually take place beyond the normal school } \\
\text { day. Students who desire to participate on athletic teams shall do so on a } \\
\text { volunteer basis with the understanding that it is a privilege and not a right to be } \\
\text { a member of a school team. All students are invited to participate, but it is } \\
\text { recognized that some students may not be capable of competing at the varsity } \\
\text { level. At non-varsity levels, participation may be restricted based on safety and } \\
\text { space restrictions. It shall be the policy of the School Department to compete in } \\
\text { interscholastic athletics sanctioned by the Rhode Island Interscholastic League } \\
\text { and to abide by that organization's rules and regulations. }\end{array}$ \\
\hline
\end{tabular}

An analysis of Table 2 brings needed clarity with regard to the context of extracurricular. Specifically, it suggests that extracurricular activities: 
- $\quad$ are outside the classroom or regular curriculum.

- $\quad$ are conducted under the auspices of the school

- do not provide a grade or academic credit

- $\quad$ are academic as well as non-academic

- $\quad$ are voluntary or optional

Using these as a foundation, a working definition can be proposed:

Extracurricular activities are defined as academic or non-academic activities that are conducted under the auspices of the school but occur outside of normal classroom time and are not part of the curriculum. Additionally, extracurricular activities do not involve a grade or academic credit and participation is optional on the part of the student.

In further review of the proposed definition, one might question whether it is overly restrictive. In particular, what happens when the extracurricular activity is closely aligned with the curriculum? To help answer this question, it is helpful to clarify another term closely associated with extracurricular; namely, co-curricular. Dictionary.Com states that co-curricular activities are "Related but only complementary to the official curriculum, as a civic or service activity outside the classroom." (italics added for emphasis, http://dictionary.reference.com/browse/co-curricular) Similarly, Merriam-Webster defines co-curricular as: "being outside of but usually complementing the regular curriculum" (italics added for emphasis, http://www.merriamwebster.com/dictionary/cocurricular).

Given these dictionary definitions, a review was then conducted to determine how co-curricular was defined in the scholarly literature. The results reveal that definitions for co-curricular are not readily available (e.g., Feldman, Aper, and Meredith, 2011; Haber, 2011; Athreya and Kalkhoff, 2010; Keen and Hall, 2009; Bresciani, 2005; Tieu, Pancer, Pratt, Wintre, Birnie-Lefcovitch, Polivy, and Adams, 2010; Pasque, et al., 2009; Kozik, Cowles, and Sweet, 2005; Junco, 2012). Instead, the concept appears to be regarded as intuitive in much the same way as extracurricular.

It was, therefore, not surprising to find that descriptors are commonly used in place of definitions. For example, Bresciani (2005) describes a co-curricular program that consists of workshops, retreats, and field experiences. Feldman, Aper, and Meredith (2011) describe co-curricular in terms of intercollegiate sports, residence life (resident hall, life/clubs and organizations), and student-managed work programs.

To help provide additional clarification, the perspectives of practitioners and the popular press were taken into account. Representative definitions from this analysis are presented in Table 3 (italics added for emphasis).

Table 3: Representative Definitions of Co-Curricular from Practitioners/Popular press

\begin{tabular}{|l|l|}
\hline \multicolumn{1}{|c|}{ Authors } & \multicolumn{1}{c|}{ Definition } \\
\hline $\begin{array}{l}\text { Round Valley High School } \\
\text { http://www.elks.net/_HS/hsguidance/eligibility } \\
\underline{\text { asp }}\end{array}$ & $\begin{array}{l}\text { Co-curricular activities are defined as those activities held in } \\
\text { conjunction with graded class responsibilities. }\end{array}$ \\
\hline $\begin{array}{l}\text { Cumberland Public Schools Co-Curricular and } \\
\text { Extracurricular Activities - General Policy } \\
\text { http://www.cumberlandschools.org/website/Int } \\
\underline{\text { erscholastic\%20Sports.pdf }}\end{array}$ & $\begin{array}{l}\text { Co-curricular programs are defined as those activities that enhance and enrich } \\
\text { the regular curriculum during the normal school day. }\end{array}$ \\
\hline $\begin{array}{l}\text { Theodore Roosevelt High School } \\
\text { http://www.kentschools.net/rhs/co-curriculars/ }\end{array}$ & $\begin{array}{l}\text { A co-curricular activity is defined as a club or group that forms, meets, or } \\
\text { practices at times } \text { other than or in addition to the regular school day and school } \\
\text { year. } \\
\text { Academic competition teams, athletics, career education clubs, general } \\
\text { opening activities, and honorary organizations are some general categories of } \\
\text { co-curricular activities in which students may participate. }\end{array}$ \\
\hline $\begin{array}{l}\text { Wikipedia: } \\
\text { http://en.wikipedia.org/wiki/Extracurricular }\end{array}$ & $\begin{array}{l}\text { Extracurricular activities should not be confused with co-curricular activities } \\
\text { such as band and choir. Co-curricular activities do have some aspects that are } \\
\text { outside the normal school day but are mainly curricular activities that happen } \\
\text { during normal class time. }\end{array}$ \\
\hline
\end{tabular}


An analysis of these definitions indicates that there is at least some disagreement regarding the general nature of co-curricular activities. For example, one definition considers athletics to be a co-curricular activity, although it is ordinarily voluntary and does not involve course credit. Additionally, some definitions state that cocurricular activities occur during the regular school hours, while others do not. Another definition includes clubs and organizations without reference to whether or not the activity is closely tied to the curriculum. Given these conflicting perspectives, more elaboration is needed to differentiate extracurricular from co-curricular.

In an effort to reconcile the conflicting descriptions, it would be helpful to consider that the prefix "co" means "together" or "jointly" (http://www.yourdictionary.com/co-prefix) indicating that a co-curricular activity is conducted along-side curricular activity. Using this as a guide, the following working definition of co-curricular is proposed:

A co-curricular activity is one that requires a student's participation outside of normal classroom time as a condition for meeting a curricular requirement.

We can now see that a co-curricular activity is similar to an extracurricular activity in that they both occur outside of the normal classroom time and they are both conducted under the auspices of the school. They differ, however, in that the co-curricular activity is required and is aligned with curriculum objectives.

One might then ask whether or not an activity can be considered both co-curricular and extracurricular. Based on the definitions, the answer would depend on the context. For example, consider the case where a student is majoring in music and, as a condition for graduation, s/he is required to participate in band activities that take place outside the normal curriculum (e.g., marching band). In this case, participation in band is considered a cocurricular activity. Now, consider another student who is majoring in business (rather than music) and joins the marching band as a non-major activity. In this context, the activity is more properly described as extracurricular. The definitions, therefore, require that any designation of an activity as either co-curricular or extracurricular consider the context.

To complicate matters, one might ask how one would classify an activity that is not required, but is nonetheless highly aligned with a student's major? For example, consider a student that is majoring in Finance and decides to join the Finance Club. Participation in the club is voluntary and is not tied to any grade or academic credit. Is this co-curricular or extracurricular? Certainly, it has aspects of co-curricular because it is closely aligned with the curriculum. Yet, it is voluntary and does not involve grading; hence, it is also aligned with the definition of extracurricular. activities:

To help resolve this conflict, it might help to propose the concepts of direct and indirect extracurricular

Extracurricular activities can be considered from the perspective of a continuum that ranges from direct to indirect. A direct extracurricular activity is one that is more closely associated with the student's major or curriculum. An indirect extracurricular activity is on that is relatively unrelated to the students major or curriculum.

Using this clarification, examples of direct extracurricular activities include such things as business majors participating in business clubs and associations, business competitions, and the like. Alternatively, a business student who plays in the school band would be engaged in an indirect extracurricular activity.

In each of these ways, the definitions provide a more secure foundation for classifying activities. As such, research that seeks to understand how these activities influence certain outcomes such as career success can then be better evaluated.

\section{CONCLUSIONS}

This literature review, along with the proposed definitions, was conducted to shed light on the meaning of extracurricular activity. The results of the analysis indicate that there currently is no generally-accepted definition. 
We have argued that this appears to have influenced the way in which extracurricular activities have been measured in the literature which, at best, can only be described as fragmented and non-systematic. As such, a major objective of this study was to synthesize the existing literature in an attempt to develop a valid definition of extracurricular activity which would thereby contribute to better classification and, subsequently, better analysis, critical reasoning and, creative problem-solving.

In the process of developing a definition, however, it was also found that any attempt would be confounded unless the term co-curricular was also clarified (given that it has also been vaguely described and appears to remain largely undefined in the literature). As such, a proposed definition of co-curricular was also provided. Finally, it was proposed that extracurricular activities be considered from a continuum ranging from direct to indirect. Together, these clarifications are intended to help ensure that research in the area of extracurricular and co-curricular activity is well-designed and executed.

With that in mind, the proposed definitions have important implications for both scholarly and practicing professionals. For scholars, the results reinforce the importance of presenting a definition for extracurricular and cocurricular activities. In doing so, subsequent classifications will likely be more valid and comparisons across related research more meaningful. We have argued that because of the relative absence of a generally-accepted definition, researchers have measured extracurricular activity in an overly broad manner which limits those comparisons. Adherence to the proposed definitions for both extracurricular and co-curricular should help mitigate these measurement issues.

From the perspective of practitioners, the implications are also intended to improve effectiveness. Principally, with the proposed definitions of extracurricular and co-curricular, school and university administration can better understand how such activities contribute to educational objectives. In particular, a better understanding of the distinction between extracurricular and co-curricular should assist the student advising process. Additionally, the distinction between direct and indirect extracurricular activity should allow students a better understanding of those activities that are more closely linked to career development objectives. To be sure, there remains a highly intuitive element in the meaning of extracurricular and co-curricular, such that the proposed definitions merely make those intuitions more transparent and formal. In doing so, however, both administrators and research scholars can have a more firm basis for making decisions, be it research designs or curriculum-related development.

In closing, it is important to acknowledge that reasonable debate can continue on the subject and that the proposed definitions represent a baseline for improving both the quality of research and the development of extracurricular and co-curricular activities. In this regard, one area that has yet to be examined is the relative value of direct versus indirect extracurricular participation on relevant outcomes, such as career success. Another area that needs more attention is whether there exists an optimal number and diversity of activities that maximizes educational outcomes (e.g., improved inter-personal skills). In other words, is more always better? In this regard, Terenzini et al. (1999) suggested that a student holding a significant leadership position in an extracurricular activity could detract from a his/her GPA and yet enhance his/her interpersonal skill development. Hence, research is needed to examine the trade-offs involved with decisions to participate in extracurricular activities.

Research is also needed that further explain the direction of influence. Rubin, Bommer, and Baldwin (2002), for example, found that holding a leadership position in a club/organization was correlated with higher interpersonal skills. We do not know, however, whether this is the result of participation or simply that individuals with higher interpersonal skills are more likely to attain leadership positions. More research is needed to clarify this finding.

Finally, Raymond, Carlson, and Hopkins (2006) found that while students may list ECA leadership roles on their resumes, they "do not explain what they did with respect to these deeds and actions; that is, what did he or she accomplish as president of an organization?" (p. 53) More research is needed to understand how a lack of explanation might hinder an otherwise positive perception of leadership roles. The definitions proposed in this study, along with the respective clarifications, are intended to help improve our ability to address these and other important issues regarding participation in extracurricular and related activities. 


\section{AUTHOR INFORMATION}

Dr. Kenneth R. Bartkus is professor of marketing and Executive Director of The Research Group ${ }^{\mathrm{TM}}$ in the Jon M. Huntsman School of Business at Utah State University and Executive Director of The Research Group. His research has been published in the American Journal of Business Education, the Journal of Travel and Tourism Marketing, the Journal of Travel Research, the Journal of Personal Selling and Sales Management, and the Journal of Professional Services Marketing, among others. E-mail: ken.bartkus@usu.edu (Corresponding author)

Blake Nemelka is a graduating senior in the Jon M. Huntsman School of Business at Utah State University majoring in marketing, business administration, and international business. He is a senior associate with The Research Group $^{\mathrm{TM}}$ at Utah State University. In the Fall of 2012, Blake will begin graduate studies at Vanderbilt University. E-mail: blakenemelka@gmail.com

Mark "Bo" Nemelka is a graduating in the Jon M. Huntsman School of Business at Utah State University majoring in marketing and international business. He is a senior associate with The Research Group ${ }^{\mathrm{TM}}$ at Utah State University. In the Fall of 2012, Bo will begin graduate studies at Yale University. E-mail: bonemelka@gmail.com

Phil Gardner is Director of the Collegiate Employment Research Institute at Michigan State University in East Lansing, MI. His work focuses on the transition from the university into the workplace including early socialization, early professional career progression and college labor market analyses. He also examines the collegiate experiences that contribute to success such as study abroad, internships, and skill/competency preparation. His work is available at www.ceri.msu.edu; E-mail: gardnerp@ msu.edu

\section{REFERENCES}

1. Adams (2002), Creative Problem Solving - short.ppt, Parallex Consulting.

2. Ahadiat, N. \& and Smith, K.J. (1994). A factor-analytic investigation of employee selection factors of significance to recruiters of entry-level accountants. Issues in Accounting Education, 99(1) 59-79.

3. Athreya, K.S. \& Kalkhoff, M.T. (2010). The Engineering Leadership Program: A co-curricular learning environment by and for students. Journal of STEM Education: Innovations \& Research, 11(3/4) 70-74.

4. Barnett, L. (2007). "Winners" and "losers": The effects of being allowed or denied entry into competitive extracurricular activities. Journal of Leisure Research. 39 316-341.

5. Belikova, L.F. (2002). Students' attitudes toward extracurricular activity in an institution of higher learning. Russian Education and Society, 44(2) 73-85.

6. Bîrzéa, C., David Kerr, D., Mikkelsen, R., Froumin, I., Losito, B., Pol, M. and Sardoc, M. (2004) Education for democratic citizenship activities 2001-2004: All-European study on EDC policies (Strasbourg: Council of Europe).

7. Boone, L.E., Kurtz, D.L., \& Fleener, C.P. (2001). CEOs: Early signs of a business career. Business Horizons, (September/October) 20-24.

8. Bresciani, M.J. (2005). Electronic co-curricular student portfolios - putting them into practice. New Directions for Student Services, (112) 69-76.

9. Brown, B.K., \& Campion, M.A. (1994). Biodata phenomenology: Recruiters' perceptions and use of biographical information in résumé screening, Journal of Applied Psychology, (79) 897-908.

10. Campion, M.A. (1978). Identification of variables most influential in determining interviewers' evaluations of applicants in a college placement center. Psychological Reports, (42) 947-952.

11. Christensen, T.E., Fogarty, T.J., \&Wallace, W.A. (2002). The association between directional accuracy and self-efficacy and accounting course performance, Issues in Accounting Education, 17(1) 1-26.

12. Clegg, S., Stevenson, J., \& Willot, J. (2010). Staff conceptions of curricular and extracurricular activities in higher education. Higher Education, 59(5) 615-626.

13. Chia, Y. M. (2005). Job offers of multi-national accounting firms: The effects of emotional intelligence, extra-curricular activities, and academic performance. Accounting Education: An International Journal, 14(1) 75-93.

14. Clotfelder, C.T. (2001). Who are the alumni donors? Giving by two generations of alumni from selective colleges. Nonprofit Management and Leadership, 12(2) 119-138. 
15. Cole, M.S., Rubin, R.S., Feild, H.S. \& Giles, W.F. (2007). Recruiters' perceptions and use of applicant résumé information: Screening the recent graduate. Applied Psychology: An International Review, 56(2) 319-343.

16. Eccles, J. S., \& Barber, B. L. (1999). Student council, volunteering, basketball, or marching band: What kind of extracurricular involvement matters? Journal of Adolescent Research, (14) 10-43.

17. Feldman, M., Aper, J.P. \& Meredith, S.T. (2011). Co-curricular assessment scale development. The Journal of General Education, 60(1) 16-42.

18. Fredricks, J. A., \& Eccles, J. S. (2006a). Is extracurricular participation associated with beneficial outcomes: Concurrent and longitudinal relations? Developmental Psychology, (42) 698-713.

19. Fredricks, J. A., \& Eccles, J. S. (2006b). Extracurricular involvement and adolescent adjustment: Impact of duration, number of activities, and breadth of participation. Applied Developmental Science, (10) 132-146.

20. Fredricks, J. A., \& Eccles, J. S. (2010). Breadth of extracurricular participation and adolescent adjustment among African American and European American youth. Journal of Research on Adolescence, (2) 307333.

21. Haber, P. (2011). Peer education in student leadership programs: Responding to co-curricular challenges. New Directions for Student Services, (133) 65-76.

22. Hakel, M.D., Dobmeyer, T.W., \& Dunnette, M.D. (1970). Relative importance of three content dimensions in overall suitability ratings of job applicants' résumés. Journal of Applied Psychology, (54) 65-71.

23. Hansen, D.M., Larson, R.W., \& Dworkin, J.B. (2003). What adolescents learn in organized youth activities: A survey of self-reported developmental experiences. Journal of Research on Adolescence, 13(1) 25-55.

24. Hough, L.M. (1984). Development and evaluation of the "accomplishment record" method of selecting and promoting professionals. Journal of Applied Psychology, (69) 135-146.

25. Howard, A. (1986). College experiences and managerial performance. Journal of Applied Psychology. 71(3) 530-552.

26. Junco, R. (2012). The relationship between frequency of Facebook use, participation in Facebook activities, and student engagement. Computers \& Education, 58(1) 162-171.

27. Keen, C. \& Hall, K. (2009). Engaging with difference matters: Longitudinal student outcomes of cocurricular service-learning programs. Journal of Higher Education, 80(1) 59-79.

28. Kerr, B.A. \& Colangelo, N. (1988). The college plans of academically talented students. Journal of Counseling \& Development, 67(1) 42-48.

29. Keser, F., Akar, H. \& Yildirim, A. (2011). The role of extracurricular activities in active citizenship education. Journal of Curriculum Studies, 43(6) 809-837.

30. Kinicki, A.J., \& Lockwood, C.A. (1985). The interview process: An examination of factors recruiters use in evaluating job applicants. Journal of Vocational Behavior, (26) 117-125.

31. Knouse, S.B. (1994). Impressions of the résumé: The effects of applicant education, experience, and impression management. Journal of Business and Psychology, (9) 33-45.

32. Kozik, L., Cowles, R.C. \& Sweet, D.J. (2005). Tying academics to co-curriculars can teach at-riskers responsibility. Education Digest, 70(5) 32-37.

33. Mahoney, J.L., Cairns, B.D. \& Farmer, T.W. (2003). Promoting interpersonal competence and educational success through extracurricular activity participation. Journal of Educational Psychology, 95(2) 409-418.

34. Marsh, H. W., \& Kleitman, S. (2002). Extracurricular school activities: The good, the bad, and the nonlinear. Harvard Educational Review, (72) 464-514.

35. McGaha, V. \& Fitzpatrick, J. (2010). Employment, academic and extracurricular contributors to college aspirations. Journal of College Admission, 207, 22-29.

36. Nelson, I. T., V. P. Vendrzyk, J. J. Quirin, and R. D. Allen. 2002. No, the sky is not falling: Evidence of accounting student characteristics at FSA schools, 1995-2000. Issues in Accounting Education, 17(3) 269287.

37. Nemanick, R.C., \& Clark, E.M. (2002). The differential effects of extracurricular activities on attributions in résumé evaluation. International Journal of Selection and Assessment, (10) 206-217.

38. Paquero, A.A. (2011). Immigrant youth involvement in school-based extracurricular activities. The Journal of Educational Research, (104) 19-27.

39. Pasque, P.A., Bowman, N.A., Small, J.L. \& Lewis, R. (2009). Student-created curricular and co-curricular pathways toward participation in a diverse democracy. Multicultural Perspectives, 11(2) 80-89. 
40. Raymond, M.A., Carlson, L., \& Hopkins, C.D. (2006). Do perceptions of hiring criteria differ for sales managers and sales representatives? Implications for marketing education. Journal of Marketing Education, 28(1) 43-55.

41. Rubin, R.S., Bommer, W.H., \& Baldwin, T.T. (2002). Using extracurricular activity as an indicator of interpersonal skill: Prudent evaluation or recruiting malpractice? Human Resource Management, (41) 441454.

42. Rynes, S.L., Trank, C.Q., Lawson, A.M., \& Ilies, R. (2003). Behavioral coursework in business education: Growing evidence of a legitimacy crisis. Academy of Management Learning \& Education, (2) $269-283$.

43. Terenzini, P.T., Pascarella, E.T., \& Blimling, G.S. (1999). Students' out-of-class experiences and their influence on learning and cognitive development: a literature review. Journal of College Student Development, 40(5) 610-623.

44. Tieu, T., Pancer, S., Pratt, M., Wintre, M., Birnie-Lefcovitch, S., Polivy, J., \& Adams, G. (2010). Helping out or hanging out: the features of involvement and how it relates to university adjustment, Higher Education, 60(3) 343-355. 
NOTES 